\title{
Doing Critical English Language Teaching: Designing critical tasks to promote critical media literacy
}

\author{
Ensinando a Lingua Inglesa de Forma Crítica: \\ O desenvolvimento de tarefas para promover o letramento midiático crítico
}

\author{
Leonardo da Silva* \\ Instituto Federal de Santa Catarina \\ Itajaí, Santa Catarina, Brasil \\ Priscila Fabiane Farias** \\ Universidade Federal de Santana Catarina \\ Florianópolis, Santa Catarina, Brasil \\ Raquel Carolina Souza de Ferraz D'Ely*** \\ Universidade Federal de Santana Catarina \\ Florianópolis, Santa Catarina, Brasil
}

\begin{abstract}
Resumo: Nas aulas de línguas adicionais em contexto brasileiro, os livros didáticos geralmente têm o papel principal de norteador do conhecimento, reproduzindo e legitimando ideologias e representações específicas do mundo (GRAY, 2010). Neste sentido, as abordagens críticas de ensino de línguas podem ser vistas como uma alternativa aos materiais de ensino de línguas hegemônicos, uma vez que levam em consideração a realidade dos alunos, problematizando-a e possibilitando transformá-la. Desta forma, este artigo tem como objetivo principal oferecer aos professores de línguas um exemplo de material que busca promover o desenvolvimento crítico linguístico (CROOKES, 2013) e o letramento midiático crítico (HOBBS, 2011) para alunos de inglês s em nível médio no Brasil. As tarefas (ELLIS, 2003) aqui descritas devem ser vistas como recursos que possibilitarão compreender, de uma forma mais prática, como promover o ensino de línguas sob uma perspectiva crítica.
\end{abstract}

Palavras-chave: Abordagem Baseada Em Tarefas. Ensino De Línguas Crítico. Letramento Midiático Crítico.

Abstract: In the Brazilian educational scenario, textbooks often function as the main foundation of knowledge in additional language classrooms, reproducing and legitimating specific ideologies and representations of the world (GRAY, 2010). Critical approaches to language teaching, therefore, can be seen as an alternative to hegemonic language teaching materials, since they look at students' reality, problematizing it and offering a

* Professor d Instituto Federal de Santa Catarina (IFSC), Campus Itajaí. Doutorando do Progiama d Pós-Graduação em In ês: Estudos Linguísticos e Literários (UFSC). Mestre em Estudos culturais pelo mesmo pr orama e Licenciado em Letras/Inglês e Literaturas (UFSC). Email: leosilva3@gmail.com.

**Mestre em Inglês: Estudios Linguisticos e Literários pela Universidade Federal de Santa Catarina. Atualmente é aluna de doutorado da Pós Graduação em Inglês: Estudos Linguísticos e Literários na UFSC, com estágio doutoral pela University of Hawaii - Manoa, como bolsista Capes/Fulbright. Email: priscilafabianefarias@yahoo.com.br.

*** Doutorado em Inglês e Linguística Aplicada e professora da Universidade Federal de Santa

Catarina. Email: raqueldely@gmail.com. 
space for transforming it. This article, hence, has as its main objective to offer teachers who are interested in critical pedagogies for language teaching a sample of materials that attempt to promote critical language development (CROOKES, 2013) and critical media literacy (HOBBS, 2011) for high school students of English in Brazil. The tasks (ELLIS, 2003) here described are to be seen as sources that can be used to understand, in a more practical stance, how to promote critical language teaching.

Keywords: Task-Based Approach. Critical Language Teaching. Critical Media Literacy.

Although the communicative language teaching (CLT) methodology has been under heavy criticism, mostly during the last three decades, from scholars who seem to have become "disillusioned with a vision of teaching as centered on the development of oral ability and with a vision of learning English as acquiring linguistic and communicative competence without a political, ideological dimension" (COX; ASSIS-PETERSON, 1999 , p. 435), this approach ${ }^{1}$ is still common in additional ${ }^{2}$ language classrooms in Brazil, usually combined with some emphasis (mostly a great one) on structural or linguistic elements. Many Brazilian teachers of English adopt a functional understanding of language in their classes, reinforcing the idea that "the best language learner is the one who easily codifies and transmits messages in the target language" (PESSOA; FREITAS, 2012, p. 755), lacking a "comprehension of language as a collection of meanings that plays an important role in how people interpret themselves and the world in which they live" (PESSOA; FREITAS, 2012, p. 755). The government official documents for education, used as a guide for curriculum development in Brazilian high schools, also claim that the focus of additional language learning must be on developing learners' communicative competence, "prioritizing the reading and comprehension of verbal and written verbal texts, - therefore, communication in different situations of everyday life" (PCN+, 2002, p. 94, our translation).

Rocha (2017) points out, however, that the reality of Brazilian schools may hamper the implementation of such goals in English classrooms due to limitations such as (i) the excessive number of students in the same class as well as the heterogeneity in terms of proficiency level among them, (ii) the deficiency in language teacher education, (iii) the insufficient amount of time reserved for the discipline within the curriculum, (iv) the poor infrastructural conditions many schools have, (v) the heavy workload teachers face daily, among others. Under such conditions, the use of textbooks becomes, therefore, more than an alternative source of language input and activities in many of these classrooms it gets to be rather a central tool in determining the discipline's program and the teachers' choices.

Considering the scenario just described, the textbook holds a significant role in education in Brazil, both as a mediating tool of subject knowledge and as merchandise

1 Although we are aware of the hot debate that has been going on for quite a while in SLA studies when it comes to define and differentiate methodology and approach, in this paper we make use of both terms interchangeably.

${ }^{2}$ We opt here for the use of "additional language" in order to avoid the idea that the focus of the teachinglearning process is the language of "the other", which is "foreign" to the students' contexts. 
that feeds the publishing industry. It is an intersectional cultural product that combines three great spheres: education, culture and market (MORAES DA SILVA, 2012). Richards (1998) explains that the textbook may function as the main source of ideas in a language classroom. Indeed, considering the various decisions that teachers have to make in schools, using a textbook or a set of materials can be helpful. Tilio (2010) talks, however, about the "dictatorship of the textbook" (p. 168), alerting to the overemphasized importance it gains in schools, as it may become the dominant voice in the process of language teaching and learning. According to the author, by taking the textbook as the primary foundation of knowledge and input, we may be "affecting the formation of students' social identities, not only influencing their view of the world, but also inducing them to adopt certain identities that may seem the right ones, ones that are socially accepted, leading them to suppress their true identities sometimes" (TILIO, 2010, p. 170, our translation).

Taking the aforementioned into account, critical language teaching can be seen, therefore, as an alternative way of teaching an additional language since it may: 1) be used to unveil the various meanings texts may have, 2) promote critical awareness, 3) celebrate multiple identities, and 4) engage students in acting upon their own context in order to transform it. However, taking into account that offering a critical perspective when it comes to language teaching may not be the main concern of textbook writers, and bearing in mind the difficulties that teachers may have when developing their own materials in Brazilian schools, this article aims at presenting a sample unit of tasks, developed for Brazilian high school students, which attempts to promote critical language learning. The following section, hence, details some of the theoretical grounds used to inform this study. Additionally, the Unit itself is detailed next and the tasks are presented and described. Then, a final reflection is made on how relevant and imperative critical language teaching is within our current world and national scenario.

\section{CRITICAL LANGUAGE TEACHING AND CRITICAL MEDIA LITERACY: A NECESSARY ALTERNATIVE}

Considering the powerful position textbooks hold as the main source of input in many additional language classrooms, it is possible to say that they function as artifacts for the ideological reproduction and legitimation of specific representations of the world (GRAY, 2010). Many are the studies that identify a neoliberal and hegemonic western perspective taken in well-known English textbooks used in classrooms worldwide, including Brazil.

Basabe (2006), for instance, looked at four series of English textbooks used in Argentinean schools and showed that representations of the stereotypical AngloAmerican culture, which were regarded or labeled as "international" attitudes, seemed to be favored in ELT textbooks. Gray's (2010) analysis of other four textbooks pinpoints individualism and spectacular professional success as central themes that are to serve as 
motivational lifestyles for students to aspire. Status and visibility were portrayed as keys to professional and personal success in eight out of the twelve textbooks examined by Tilio (2010), mostly represented through an American and European view of the world. Tilio also found that different from textbooks made for intermediate students, the ones that focus on developing skills of beginners tend to present an ideal and perfect world, addressing neutral themes without problematizing students' realities. Caukill (2011) investigates intercultural representations in two textbooks, revealing that western identities, cultures and ideologies still predominate in visual and textual representations. Focusing on gender representations that may permeate textbooks, Ferreira and Brigolla (2013) analyzed the textbook Take your Time (ROCHA; FERRARI, 2004), and showed how stereotypical representations of women and men in the professional sphere still dominate.

Critical approaches to language teaching and the inclusion of a wider variety of cultural content can be seen as alternatives that look at students' reality, problematizing it and offering a space for transforming it. In this direction, Tomlinson (2012) states that "it is important that teachers and language courses focus on developing constructive criticality as one of their objectives" (p. 165) when using textbooks. Another possibility is adapting or developing their own materials. D'Ely and Mota (2004) emphasize that the role of teachers when it comes to textbooks involves personalizing the material and the teaching methodologies as well, adapting them to the learners' needs. If teachers develop or adapt materials according to students' needs and context, there is a bigger chance that they will become engaged citizens, reflecting and acting upon uses of language from a critical perspective which in turn tends to be much more meaningful and useful in their lives. As explained by Caukill (2011),

by questioning what exactly is being taught and how the language and visual images are being presented, along with casting a critical eye on the contents, the identities of the people in ELT textbooks, the relations in which they are involved and being aware of any biases and "silences", teachers can help to determine what ideologies are being upheld, and if these are appropriate for the learners (p. 69).

Pennycook (1999) highlights the importance of a transformative pedagogy, one that "aims to do more than describe pessimistically what is wrong and instead suggests possibilities for change" (p. 335). Crookes (2013) calls attention to the role of needs analysis when implementing critical language teaching. According to the author, addressing students' needs and acknowledging who they are in their setting is a way to promote agency and autonomy. Pessoa and Freitas (2012) give equal importance to teachers' critical agenda, considering the teachers' perceptions on topics that may be relevant to a certain group. The latter authors agree with Pennycook (1999) who mentions class, race, gender, sexuality, ethnicity and representations of otherness as classic topics that can be tackled as a way to explore power relations operating in social life.

Although adopting a critical position in language teaching seems to be a valid and significant alternative in English language classrooms, schools' realities and teachers' 
working conditions may still impose limitations when it comes to materials development. In this sense, Crookes (2013) alerts to the important role of materials examples that may serve as the starting point to teachers who aim at implementing critical ELT. As stated by the author, “in critical language pedagogy, we don't actually have as many of these accounts and examples as exist in other areas of second language curriculum (or of critical curriculum, for that matter)" (p. 9). One goal of this article is, therefore, to offer teachers, who are curious or interested in critical pedagogies for foreign language teaching, a sample of materials that attempt to promote critical language development for students of English as an additional language in the Brazilian context. More specifically, the materials described here aim at approaching media texts from a critical perspective. Thus, one of the main objectives is to promote Critical Media Literacy (CML).

As Kellner and Share (2007), explain:

Critical media literacy expands the notion of literacy to include different forms of mass communication and popular culture as well as deepens the potential of education to critically analyze relationships between media and audiences, information and power. It involves cultivating skills in analyzing media codes and conventions, abilities to criticize stereotypes, dominant values, and ideologies, and competencies to interpret the multiple meanings and messages generated by media texts (p. 4).

In this sense, critical media literacy goes beyond understanding, analyzing, and evaluating media messages by proposing that students engage with media texts so as to create their own meanings and messages. Because of that, critical media literacy is congruent to Critical Pedagogy, which is not only about understanding the word and the world (FREIRE, MACEDO, 1987), but also about promoting change, that is, about acting upon reality (even if it is at a local level). This means that it is not enough to understand the ideology behind media messages - it is necessary, in this sense, to promote new meanings to challenge such messages.

Due to the fact that promoting critical media literacy can be seen as quite challenging, Hobbs (2011) describes a model for media literacy that encompasses five competencies: accessing, analyzing, creating, reflecting, and acting (p. 12). In brief words, 'Accessing' means "finding and sharing appropriate and relevant information and using media texts and technology tools as well” (p. 12). The second competency, 'analyzing', has to do with understanding the purpose of a message within its sociopolitical context. 'Creating' implies "composing or generating content using creativity and confidence in self-expression, with awareness of purpose, audience, and composition techniques" ( $p$. 12). The fourth competency, 'reflecting', comprises understanding the effects media messages play in our lives and acting upon them responsibly and ethically. At last but not least, 'acting' is "working individually and collaboratively to share knowledge and solve problems in the family, the workplace, and the community, and participating as a member of a community at local, regional, national, and international levels" (p. 12). In this sense, critical media literacy can be seen as aligned with the premises of Critical Pedagogy to the extent that it goes beyond the comprehension of messages by proposing action that may 
foster social justice, that is, action that is guided by an ethical, responsible, and collaborative stance.

Media literacy is an area in its own right - besides being implemented through different perspectives, its importance has been recognized across various disciplines in the school curriculum (mostly in the Unites States). Our focus here is on media literacy that may account for a critical perspective for English language teaching. In other words, the tasks herein proposed were developed from the perspective of Critical Pedagogy and following Hobbs' five-competency model for critical media literacy. As Robertson and Scheidler-Benns (2016) explain, even though the need for CML has been widely recognized, it has rarely been implemented in the classroom context. In this sense, there have been few accounts of critical media literacy pedagogical practices, especially when it comes to ELT.

\section{CRITICAL LANGUAGE MATERIALS: PROPOSING A SAMPLE}

According to Crookes (2013), most teachers' pedagogical choices are highly influenced by the different teaching practices they have been exposed to, be it as students or as student-teachers. However, in spite of having a long history of this apprenticeship of observation, "few teachers have had the opportunity to actually observe critical language pedagogy" (p. 1). It is in this sense that sample materials are called for - even though Critical Pedagogy regards the development of materials as being contextdependent and based on the students' specific needs and wants, sample materials find relevance to the extent that they can serve as models on how to implement the principles of critical language teaching. Thus, "teaching materials in particular are important because they may provide, to language teachers new to the topic, a concrete sense of where a teacher could start and also an idea of what some critical language pedagogy classrooms have looked like" (CROOKES, 2013, p. 9).

As we have seen, the need to develop specific critical materials for the language classroom also finds relevance on the fact that textbooks in general have not catered for the necessities of promoting an education that is based on social justice and that supports the "development of active, engaged citizens who will, as circumstances permit, critically inquire into why the lives of so many human beings, perhaps including their own, are materially, psychologically, socially, and spiritually inadequate" (CROOKES, 2013, p. 8). In addition, the few critical material samples that are available focus on the intermediate and advanced second language learner (CROOKES, 2013, p. 13). As language educators who work primarily with basic and technological education in the Brazilian context and with beginner students, it is our intent to contribute to this area by devising sample materials for the Brazilian additional language teaching context.

As we describe the activities that were developed, it is important to keep in mind that the materials here presented are based on the Task Based Language Teaching (TBLT) framework. TBLT can be seen as a branch of the Communicative Language Teaching approach in the sense that it fosters the development of the communicative competence 
through the use of tasks as the instrument of instruction for teaching and learning. Ellis (2003) defines tasks as activities that, among other characteristics, offer the learners an opportunity to focus their attention on meaning-making and on conveying the message while attempting to achieve an outcome that is based on real-world activities. Moreover, within TBLT, there is room for focusing on form based on the student's needs and learning goals.

Another important aspect of the TBLT framework informing the material developed for this study has to do with task sequencing. As explained by Van den Branden (2016), a number of authors (e.g. SKEHAN, 1996; WILLIS; WILLIS, 2007) have proposed pedagogical guides in the field that introduce "a three-stage model which consists of pre-task activities, the actual task performance and post-task activities" (p. 242). In this article, the two pre-task activities developed aim at introducing the main theme of the Unit and engaging learners in a critical reflection concerning this theme. Moreover, they serve as linguistic input for the following task. The actual task intends to aid students in writing in the target language aiming at transforming their own reality based on the critical reflection in which they have previously engaged in. The post-task stage, which gives room for reviewing the actual task, as well as for focusing on form depending on the students' needs or even for moving forward with the goal of the actual task, will depend on the outcome of the actual task which, in turn, will be based on the learners' choices and decisions. A more detailed explanation of each task is presented in the next section.

It is important to acknowledge, however, that although TBLT is built on philosophical underpinnings such as learner-centered approach, egalitarian teacherstudents relationship and participatory democracy (LONG, 2015), which are similar to some principles that ground Critical Pedagogy and Critical Media Literacy, the main focus of research in the TBLT field is of a cognitive nature and the objective of using tasks in the language classroom is to promote effective communication. It is our belief, nevertheless, that teaching an additional language is preparing learners for engaging with discourse critically, so as to act upon their world and transform it. In this sense, we side with Shor (1992) who claims that education should have an "agenda for empowerment" (p. 11) in which students become critical, skilled and active citizens. Therefore, the materials here proposed are task-supported, since the activities were developed under the task-based framework. These tasks, in turn, have as their main goal to aid learners in developing additional language literacy and media literacy from a critical perspective.

It is also necessary to recognize that the activities we suggest are supposed to serve as an initial step towards understanding how to implement Critical Pedagogy principles in language teaching. In this regard, our purpose is by no means to devise a specific methodology or fixed guide for making language classes critical, since that would go against the very principles of Critical Pedagogy. Rather, the objective is to instigate other educators in thinking about how such activities might (or not) function in their contexts, and how they could be adapted, changed and even improved. Furthermore, it is important to acknowledge the important role of the teacher's mediation in the implementation 
process, since it is not the activity by itself that will guarantee a critical approach to language teaching (in the same token, a non-critical material may be approached from a critical perspective by the teacher and also by the students themselves).

It is also pertinent to mention that the need to approach language teaching from a critical perspective in basic education goes hand in hand with the overall objective of schooling - in this sense, if we are to understand education as contributing to the development of the skills that are necessary for the upbringing of critical and active citizens, Critical Pedagogy can be seen as an important tool to move beyond the traditional paradigm of knowledge transmission or the so-called 'banking system' (FREIRE, 1970).

In this sense, Van den Branden (2015) postulates that the traditional school system needs to focus on the so-called $21^{\text {st }}$ century skills. More specifically, the author argues that the school needs to: make language and information work, make knowledge work, make creativity work, make social diversity work, make change work, make one's learning potential work, make one's life work, and make life on the planet work. What the author means by that is that the schools in general have not reflected the changes of our complex society - it is in this sense that the traditional educational system has failed. Therefore, it is important not only to provide the students with information (since information can be accessed basically anywhere and without the guidance of a teacher or the presence in a school environment), but also to make them develop a critical stance towards the information that is available and that is so commonly consumed. Furthermore, it is important to put knowledge to good use (VAN DEN BRANDEN, 2015), so as to develop the ability to come up with creative solutions for problems concerning not only oneself but also other people in a given society. As we can see, these skills can be considered as directly related to the ones that should be developed from the perspective of critical media literacy. It is with the aim of developing these different skills and postures that we came up with the activities that will be described below.

\section{A CRITICAL MEDIA LITERACY UNIT: CHALLENGING STEREOTYPES IN MEDIA TEXTS}

Bearing in mind the need for the school to develop the so-called $21^{\text {st }}$ century skills as well as the ubiquity of technology in the students' lives, we decided to approach the topic - "Stereotypical portrayals in media texts and the possibility of promoting new perspectives through technology/social networks". In this sense, the content to be discussed is related to the development of both language and critical media literacy skills, since the activities suggested within the article deal with texts and their contexts, that is, we seek to show how texts shape and are shaped by their contexts. More specifically, the theme we chose to examine dealt with general and common representations of Africa in the media. Even though such a topic may seem distant from students' reality, we decided that it would be important to first look at the issue of media representation at a global level and then analyze it at the local level. Moreover, stereotypical representations of Africa pervade students' imaginary and are most probably constructed through the 
different images they see in the media (most often reproduced by images and texts coming from the so-called developed countries, such as in the case of mainstream movies, television series, and news programs).

The tasks here described were developed for high school students who beginners (Level 1 of English) are taking a technical course integrated in their high school studies in this sense, the activities aim at developing their communicative and critical skills, so as to allow them to act consciously in the world. These students go to a Federal Technical Institute in Southern Brazil, and their ages vary from 15 to 18 years old. Considering this teaching context, we are aware that these students have access to the internet (since their school has wifi connection), and they make constant use of their cellphones and other technological devices in their daily lives. Although we acknowledge that this is not the reality of many schools and students in Brazil, we reinforce the idea that the materials here detailed are to serve as samples for teachers to reflect about their own context when attempting to promote critical English teaching. Therefore, these very materials can (and should) be adapted to different contexts and/or simply serve as an example for teachers to develop their own materials that accommodate their students' needs and realities.

More specifically, the general objectives of the tasks in this unit are: i) Reflect critically by unveiling possible meaning(s) produced by different media genres; ii) Develop reading strategies for the comprehension of different textual genres; iii) Understand the role of technology and social media for the promotion of social justice; and iv) Reflect about the implication of media and technology in society. Therefore, it is expected that, at the end of the proposed unit, the students should reach certain specific objectives, as summarized in the chart below.

\begin{tabular}{|l|}
\hline \multicolumn{1}{|c|}{ Specific objectives } \\
\hline At the end of the Unit, students should be able to: \\
- Understand how meaning can be constructed in different textual genres (i.e. magazine \\
covers, social media posts, and written speeches); \\
- Use different reading strategies in trying to comprehend texts in English (i.e. recognize \\
cognates, understand the use of suffixes such as "-less" and "-ous", use \\
skimming/scanning strategies, understand how the context shapes the text, etc.); \\
- Think of ways in which technology can be used as a counter-discourse to stereotypical \\
representations in the media; \\
Relate the issue of cultural stereotypes to their contexts and disseminate stories of \\
people that are not usually heard or promoted in the media.
\end{tabular}

In order to accomplish the aforementioned objectives, three main strategies were used while developing this lesson: (1) challenging media texts, (2) reading and writing beyond stereotypes, (3) transforming our own reality. The lesson was also based on Hobbs' (2011) competencies model for critical media literacy. Even though the five competencies described by Hobbs (2011) may overlap, the first part of the lesson - 
challenging media texts - focuses on accessing and analyzing media texts. The second one - reading and writing beyond stereotypes - deals with the abilities of creating and reflecting, and the last one - transforming our own reality - relates to the competency of acting.

The following paragraphs, therefore, describe the tasks within each of the mentioned strategies. Each section starts with a theoretical contextualization that guided our choices, followed by two sub-sections - Introducing the Task and Guiding Students' Reflections - that aim at describing, at a practical level, issues concerning how to go about implementing the material in the classroom. It is important to clarify, however, that many other decisions referring to the implementation of these materials are not mentioned since they should be decided by the teacher and the students, according to each context of instruction. The tasks themselves are also presented here throughout the body of each section.

\subsection{ACCESSING AND ANALYZING: CHALLENGING MEDIA TEXTS}

As we are constantly exposed to innumerous texts through media, we must find ways to cope with the great amount of information received. Readers have to be aware that not only the literal message, but also other aspects of the text carry meaning that are related to the author's intent, the purposes in producing such text and the ideas that are (or not) being conveyed. Asking questions such as "whose viewpoint is expressed in this text and whose is not?", "what world representations are being portrayed here and why?," and "what aspects (textual or not) seem to contribute to this representation?", among others, is part of the critical reader's role in unveiling meaning from text.

In the first part of the proposed unit, therefore, students are asked to reflect about how meaning is constructed through the use of different resources in magazine covers. More specifically, during the first pre-task, they reflect about how the different choices made (such as colors, fonts, and images) help create a specific image of the African continent.

\begin{tabular}{|c|c|}
\hline $\begin{array}{l}\text { Introducing } \\
\text { the task }\end{array}$ & $\begin{array}{l}\text { First, in order to prepare students for the first task, the teacher may show } \\
\text { any magazine cover and focus on the understanding of the genre: s/he } \\
\text { discusses with students how elements such as words, images, colors, fonts, } \\
\text { etc., contribute to the creation of meaning within that genre. We encourage } \\
\text { the teacher to conduct the discussion in English, trying to make use of the } \\
\text { cover and the blackboard as aids to scaffold students' comprehension. } \\
\text { Then, the teacher presents images from magazines depicting different } \\
\text { countries in the African Continent (i.e. Kenya, Tanzania) and asks the } \\
\text { students to identify which places are being represented in those covers. After } \\
\text { distributing Task } 1 \text { to the students, the teacher reads the instructions with } \\
\text { them and confirms their understanding on what they are expected to do. }\end{array}$ \\
\hline
\end{tabular}




\section{Task 1}

Have a look at the two TIME magazine covers and, in pairs, complete the following questions.

a - Identify the words on the covers that are familiar to you. Then, include them in the boxes below according to their meaning.

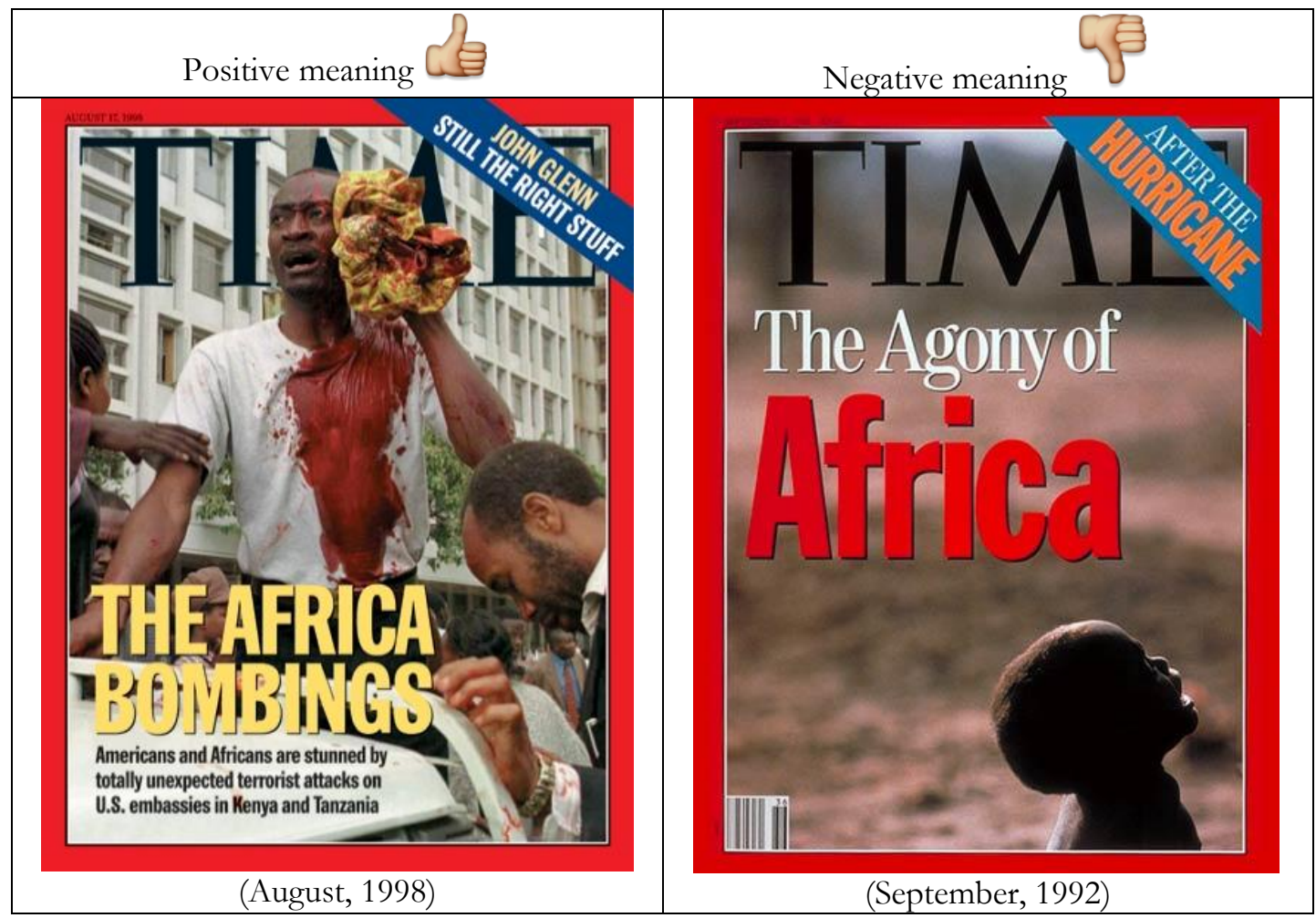

Images retrieved from http://content.time.com/time/covers.

$\mathrm{b}-$ What images are presented? Are they positive or negative representations? Why?

c - What are the colors used in the covers? What can they possibly represent? 
$\mathrm{d}$ - Considering your answers for letters a, b and c, how is Africa being represented in these two magazine covers? Explain.

e- In your opinion, is this representation of Africa common? What other words are, in general, associated with Africa? Are they positive or negative?

\begin{tabular}{l|l}
\hline & $\begin{array}{l}\text { After students are finished discussing the questions with their peers and } \\
\text { answering the task, the teacher corrects it with the entire class. The teacher } \\
\text { may ask extra questions to instigate students' reflections such as why such } \\
\text { representations of Africa are so common in the news and others are not (for }\end{array}$ \\
Guiding \\
instance, we hardly ever hear of successful people from Africa); considering \\
Reflections \\
the origin of the magazine, whose perspective of Africa is being portrayed \\
and for what audience? how important are the identified design aspects to \\
convey the intended message? etc. This extra discussion may be conducted \\
either in English or in Portuguese, according to the teacher's choice, taking \\
the context into account.
\end{tabular}

By posing questions, unveiling non-literal meanings within the chosen texts, and problematizing these meanings, students are expected to practice and learn language within a critical perspective, understanding the existing biases and purposes that constitute those texts.

\subsection{CREATING AND REFLECTING: READING AND WRITING BEYOND STEREOTYPES}

In the second part of the Unit, students are encouraged to reflect on alternative representations of the world by looking at other texts and even by producing their own texts. At this point, the goal is to guide learners in perceiving that different voices tell different stories about the same situation, and the reason why some voices are more frequently heard than others is not coincidental, and this usually reflects power relations in society. In Pre-task 2, therefore, students read and write beyond the stereotypes they found in the previous activity.

In this sense, Pre-task 2 requires students to read an excerpt of the transcript of a TED (Technology, Entertainment and Design) Talk given by the feminist Nigerian writer Chimamanda Adichie. In her talk, Adichie discusses the problem of presenting a 
stereotypical image of different things in life, different places, especially Africa, the continent where her home country is located. She talks about her experience as a child to demonstrate the dangers of only getting to know a "single story", that is, a single version or perspective of something, as the title of the text itself suggests. Because the text is longer than the one in Pre-task 1, and may contain many words students are not familiar with, the task starts with a preparatory phase that introduces students to reading strategies in order to cope with comprehension difficulties that may arise. Next, students discuss and voice their opinion about how stereotypical portrayals can be problematic, proposing alternative representations to the texts in Pre-task 1.

Introducing the task
The teacher explains that the students will continue reflecting about this topic through a TED Talk. S/he asks them whether they know what a TED Talk is and whether they know writer Chimamanda Adichie. The teacher may project some of the author's biographical information and ask students to identify who she is, how old she is, what she does, where she is from, etc. The teacher may also show the website TED Talk and guide students towards understanding what this is, in case they do not know. As a final preparation step, the teacher may project the title of the TED Talk transcript they will read in Task 2 and work with the students on predicting what it will be about, considering cognate words and their background knowledge. After distributing Task 2 to students, the teacher reads the instructions with them and confirms their understanding on what they are expected to do. Letters a, $\mathrm{b}, \mathrm{c}$ and $\mathrm{d}$ are to be done separately, one by one, and the teacher may correct each one before handing in the next. The whole discussion for introducing the task is encouraged to take place in English.

\section{Task 2}

a- Imagine that you decided to print Adichie's talk to read it carefully. However, your printer had a problem and now you cannot read a few words from the text. Even so, take a look at the text and answer the following questions.

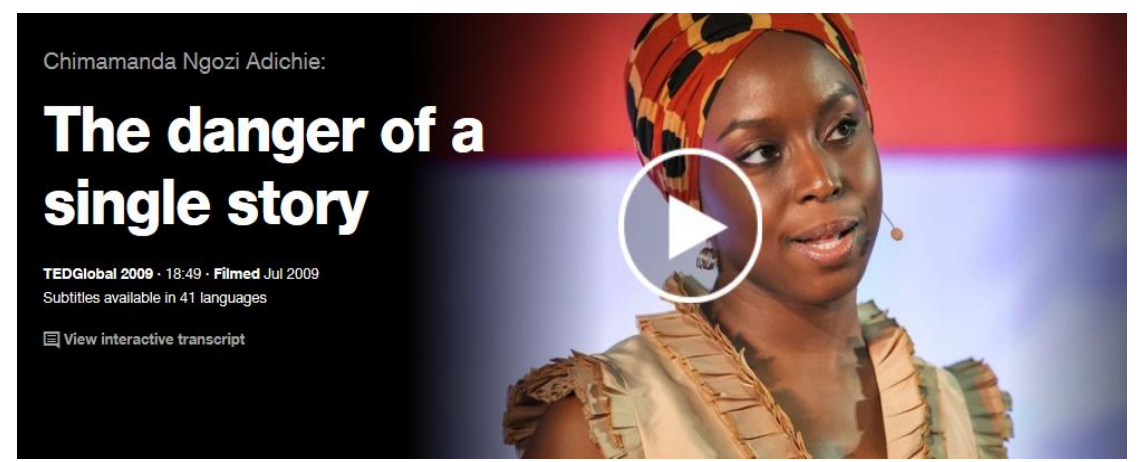

Image retrieved from:https://educationmatters01.files.wordpress.com/2014/12/singlestory.png 


\section{THE DANGER OF A SINGLE STORY - CHIMAMANDA ADICHIE}

I had grandfathers who died in refugee My cousin Polle died because he could not get healthcare. One of my closest friends, Okoloma, died in plane crash because our firetrucks did not have water.

All of these stories make me who I am. But to insist on only these stories is to flatten my experience, and to overlook the many other stories that formed me. The single story creates And the problem with stereotypes is not that they are untrue, but that they are incomplete. They make one story become the only story.

Of course, Africa is a continent full of catastrophes. There are immense ones, such as the rapes in Congo. And depressing ones, such as the fact that 5,000 people apply for one job vacancy in Nigeria. But there are other stories that are not about catastrophe. And it is very important, it is just as important, to talk about them.

The consequence of the single story is this: it robs people of dignity. It makes the recognition of our equal humanity difficult. It emphasizes how we are different rather than how we are

(excerpt retrieved from

https://www.ted.com/talks/chimamanda adichie the danger of a single story/tra $\underline{\text { nscript?language }=\mathrm{en}}$ )

1 - Take a quick look at the textand focus on the words that are familiar to you. What is the main idea of "The Danger of a Single Story"?

Main idea:

2 - Now have a look at the words below. Where do they fit in the text? Think about their meaning and the context of the text.

\begin{tabular}{|c|c|c|c|c|c|}
\hline horrific & camps & adequate & stereotypes & negative & similar \\
\hline
\end{tabular}

3 - Read the text again to identify the topics to complete the table below:

\begin{tabular}{|l|l|}
\hline Examples of single stories & Consequences of the single story \\
\hline & \\
& \\
\hline
\end{tabular}


$\mathbf{b}$ - Based on your experience in the previous activity, what can you conclude?

1) ( ) It's not necessary to understand all the words in a text.

( ) It's necessary to understand all the words in a text.

2) ( ) I need to read the complete text to understand the main idea.

( ) The way I read the text depends on my objective for reading.

3) ( ) I only need information that is in the text.

0 The context (title, information about the author, images, etc.) helps me in understanding the main ideas of the text.

\begin{tabular}{c|l}
\hline $\begin{array}{c}\text { Guiding } \\
\text { Students' }\end{array}$ & $\begin{array}{l}\text { After students are finished answering questions 'a' and 'b', the teacher } \\
\text { corrects them with the entire class. The teacher may ask extra } \\
\text { Reflections } \\
\text { on Reading } \\
\text { strategies }\end{array}$ \\
$\begin{array}{l}\text { are familiar with when reading texts and how important these } \\
\text { strategies are for their language development. Next, the teacher may } \\
\text { hand in the rest of Task } 2 .\end{array}$ \\
\hline
\end{tabular}

c - Discuss the question below with a classmate.

According to Adichie, "there are other stories that are not about catastrophe. And it is very important, it is just as important, to talk about them". Do you agree with her? What are some examples of other stories that are not about catastrophes?

d-Look for information about Africa that is not related to catastrophes. In groups, design your own magazine cover portraying your piece of news. To prepare, first complete the table below.

\begin{tabular}{|l|l|l|}
\hline \multicolumn{1}{|c|}{ Resources } & \multicolumn{1}{|c|}{ Your Choices } & $\begin{array}{c}\text { Explanation for your } \\
\text { choices }\end{array}$ \\
\hline $\begin{array}{l}\text { What representation of Africa } \\
\text { are you going to portray? }\end{array}$ & & \\
\hline $\begin{array}{l}\text { Whose perspectives/voices are } \\
\text { you going to portray? }\end{array}$ & & \\
\hline
\end{tabular}




\begin{tabular}{|l|l|l|}
\hline What is your news headline? & & \\
\hline $\begin{array}{l}\text { What colors are you going to use } \\
\text { in your magazine cover? }\end{array}$ & & \\
\hline $\begin{array}{l}\text { What images are you going to } \\
\text { use? }\end{array}$ & & \\
\hline
\end{tabular}

\begin{tabular}{c|l}
$\begin{array}{c}\text { Guiding } \\
\text { Students' } \\
\text { Reflections } \\
\text { on }\end{array}$ & $\begin{array}{l}\text { After students are finished discussing and answering letters c and d with their } \\
\text { peers, the teacher checks it with the entire class. The teacher may use this } \\
\text { moment for encouraging a group discussion with the goal of reflecting about } \\
\text { the ways in which stereotypical images are constructed by the media. The } \\
\text { discussion can be done both in English and Portuguese. Then, in order to } \\
\text { prepare for letter d, the teacher may discuss with students how to write a } \\
\text { headline of a piece of news. That means identifying the most important } \\
\text { information of the news, choosing words that represent this information, } \\
\text { writing a clear and interesting but short sentence, and so on. The teacher may } \\
\text { use examples of other pieces of news to illustrate how headlines are written } \\
\text { or ask students to research by themselves and come up with some strategies } \\
\text { to write their own. Based on the examples, the class can come up with a list } \\
\text { of common words or expressions normally used in headlines, so as to } \\
\text { provide students with input. Next, students can engage in producing their } \\
\text { own magazine covers, using their headlines. }\end{array}$ \\
\hline
\end{tabular}

By creating new versions of the magazine covers, students are expected to practice and learn language within a critical perspective, exploring different viewpoints of Africa and reading and writing beyond the stereotypes related to this continent and its people.

\subsection{ACTING: TRANSFORMING OUR OWN REALITY}

After reflecting about the ways in which stereotypical images are constructed by the media, students are encouraged to reflect on ways to assign different meanings (that is, to challenge the hegemonic representations) through the use of technology. However, this time, they are invited to reflect about their own reality as an attempt to confront socially constructed roles, identities, and situations that are relevant to their own lives. By doing so, students go beyond the critical reading of texts to become engaged actors in transforming their context and promoting change.

Task 3, therefore, asks students to tell stories of people they know, of people in their community or even their own stories, with the aim of raising multiple voices and avoiding single stories of their context.

\begin{tabular}{c|l}
$\begin{array}{c}\text { Introducing } \\
\text { the Task }\end{array}$ & $\begin{array}{l}\text { In order to prepare for the actual task, the teacher starts by asking students } \\
\text { how important social media is in shaping their reality. The focus here is to }\end{array}$ \\
\hline
\end{tabular}


guide students in understanding the impacts media has in our lives, both on a general and on a personal level, since we use social media to get informed about what is happening in the world and to share what is happening to us. The teacher, then, may ask students to identify single (that is, stereotypical) stories that are part of their reality. Following that, learners can talk about their community, their school, their families, and their own experiences as individuals. Then, the teacher may encourage them to think about other perspectives that could be told in relation to their reality, in order to raise multiple voices and tell more than a single story. This discussion can be done in English or in Portuguese, according to the context. However, in case the discussion is done in Portuguese at first, the teacher could try to wrap up the discussion and review the main points in English, making use of tools such as the board, so as to have a summary of the main ideas in English to be used in Task 3. After distributing Task 3 to students, the teacher reads the instructions with them and confirms their understanding on what they are expected to do.

\section{Task 3}

a) Now that we have discussed the power of media and the potential to promote multiple stories through social media and technology, reflect with your person the issues which follow:

Do you know any stories that in your view deserve to be shared? For example:

- people in your school;

- people in your family or community;

- immigrants in your city;

- poor communities in your neighborhood;

- a project in your school or in your community;

- an experience that you have lived.

\section{NOTES:}

b) What can we do online in order to share such stories (create a webpage? A blog? A Facebook page? An Instagram page?). 
We will use these ideas above to reflect on our final project for this Unit! It will be a collaborative decision!

\begin{tabular}{c|l}
$\begin{array}{c}\text { Guiding } \\
\text { Students' } \\
\text { Reflections } \\
\text { on }\end{array}$ & $\begin{array}{l}\text { After students are finished discussing the questions with their peers and } \\
\text { answering Task 3, the teacher goes over the activity with the entire class. The } \\
\text { idea here is to identify common themes and/or protagonists in the stories } \\
\text { students think are important to tell. This task is a preparation for the final } \\
\text { project of the unit, which involves sharing stories that are part of students' } \\
\text { realities online. Collaboratively, then, students and the teacher will choose } \\
\text { the platform, the way stories will be told, whose stories, if they will share a } \\
\text { similar theme or not, etc. When the time to write the story itself comes, the } \\
\text { teacher may work with strategies for writing a narrative such as providing an } \\
\text { outline for students to base themselves on or identify the main elements of } \\
\text { the chosen genre to serve as basis for students to make their choices. The } \\
\text { teacher may use other narratives as examples to aid students with input } \\
\text { related to the genre itself and language. Moreover, the teacher may develop } \\
\text { new tasks that work with specific language students may choose to work } \\
\text { with. The complexity and length of the text will depend on students' } \\
\text { linguistic level and well as on their content decisions. Also, students may use } \\
\text { the previous activities and other materials to serve as input. }\end{array}$ \\
\hline
\end{tabular}

There are different ways in which the students could decide to take action in Task 3. One way used by our students, for instance, was through the creation of their own version of the page "Humans of New York", which features the stories of common people in the city of New York. In this sense, they interviewed the different people that are important to the school environment - teachers and educators in general, school workers, students, parents, and so on - and told their stories in a page they called "Humans of our school". From a critical perspective, by telling the stories of different people in the school community, not only are the students reflecting about and valuing diversity, but they are also sharing stories of those that are not usually heard or represented by the media. Besides, the project could be understood as an exercise of empathy; after all, by getting to know other people's stories one can relate to them or even see a certain issue or situation from a different perspective.

In this last section of the Unit, the outcome will, therefore, highly depend on the students' contributions - after all, it is the students themselves who will decide on what is relevant to be told and on how that should happen. It is always relevant to point out that a participatory curriculum is a very important component of Critical Pedagogy. However, engaging students in the process of decision-making and in exercising their

${ }^{3}$ To know more about the "Humans of New York" project, visit http://www.humansofnewyork.com. 
agency is indeed a great challenge. That is why we believe that a set of structured and guided introductory tasks (such as 1 and 2) may serve as a starting point for more participatory activities to take place. As Crookes (2013) suggests, "this can mean use of pre-written sample materials, preferably as a way to get things going, and preferably supplemented or overridden rapidly by content brought in by students, suggested by them, and in this day and age, in well-resourced classrooms, found by them on the internet" (p. 67).

This is not to say, however, that Tasks 1 and 2 do not have the student at the heart of language teaching and learning. In fact, the very theme of stereotypical representation of the media was chosen for this specific context based on the students' constant use of technology (even in the classroom, in which the use of cell phones has raised controversies among teachers, parents and students $\left.{ }^{4}\right)$. Not only that, but the activities were thought so as to promote critical dialogue and to engage students in a process of understanding and reflecting about media messages. Once again, it is important to mention that the way the teacher implements the activities plays a fundamental role in determining whether or not they will promote critical media literacy.

The post-task stage of this Unit will also depend on the outcome of Task 3. Depending on students' difficulties with language, the teacher may use this moment to focus on form (LONG, 1991), and work on improving students' linguistic outcome. Then, students may rewrite their own texts, engaging in an activity that provides the opportunity for (re)conceptualizing and (re)formulating the intended message (BYGATE; SAMUDA, 2005). Another option for a post-task is reflecting on the real impact of their texts in their school community and thinking of other ways to promote transformation. Once again, we reinforce the importance of developing and adapting materials according to the context and students' needs.

The tasks here presented contain all the steps that, according to Hobbs (2011), are necessary for the development of critical digital and media literacy: accessing, analyzing, creating, reflecting, and acting (p. 12). In this sense, not only do the students access and analyze the ways in which certain media messages are constructed, but they also reflect about the implications these medias may have in society and act upon them by creating new representations and by considering local problems. The topic - which may be seen at first as disconnected from their reality, since it deals with the representation of Africa - is actually intended to relate to their own lives through the activities. Thus, the problem of representation is dealt with at a global and at a local level.

\footnotetext{
${ }^{4}$ A state law in Santa Catarina (14.363/08) prohibits the use of cell phones in schools. In this sense, instead of recognizing the potential that technology may bring to education, and promoting the students' awareness regarding the use of cell phones and media messages in general - that is, the development of media literacy -, a protectionist approach that is inherently non-critical and outdated is adopted.
} 


\section{FINAL REMARKS}

The tasks presented and discussed in this article have the objective of shedding some light on ways to develop critical materials for the English language classroom. More specifically, we focused on the development of a critical stance towards media messages by using as a guide the five-competency model that should be developed in critical media literacy (HOBBS, 2011). As for the language approach, the activities were based on the Task-Based Language Teaching framework, which makes use of tasks as their teaching instrument.

Firstly, we should not forget that, as we have tried to make clear, any attempt to implement classes from the perspective of Critical Pedagogy needs to take into consideration the teaching context one is inserted in. In this sense, the tasks presented here are not supposed to work as a "recipe" that could be applied anywhere - rather, students' different characteristics and the several variables that are part of each teachinglearning context need to be considered beforehand. In the case of our tasks, for instance, it would be important to understand the students' relation with media messages and their access to technological devices, just to name a few aspects.

Since many textbooks do not meet the needs of teaching contexts (and many actually end up reproducing hegemonic ideas from a non-critical perspective), it is paramount to have more examples of how to do critical language teaching. Not only that, but also systematic research on the implementation of critical activities in the language classroom is called for. Besides, as we have tried to emphasize, it is not the activity per se that will make a class critical. Instead, it is important that teachers have - or develop, since this is a never-ending process - a critical perspective towards teaching so as to act as a mediator who will help students to understand, critically analyze, and act upon social inequality. In this sense, we argue that teacher education programs should also be conceived and carried out from a critical perspective.

Another important aspect to be considered is that our goal here is not to reject textbooks that do not have a critical perspective as the primary concern or to preach for the use of one single approach over another. Similarly, we do acknowledge the underprivileged reality of many schools in Brazil and the many difficulties local teachers of English face daily, and that, many times, prevents them from developing their own materials, among other decisions. However, we side with Moita Lopes (2012) who states that teaching an additional language is promoting "the engagement of the student with discourse, hoping that he/she can use it to make ethical choices about the social world that mirror the possibility of refuting any type of human suffering" (p. 1, our translation).

Finally, one may ask whether it is really necessary to adopt a critical perspective to language teaching. In this case, we should ask, "what is the cost to society if the one-sided positions in text and in media are unquestioned?" (ROBERTSON; SCHEIDLERBEENS, 2016, p. 2253). Or: what are the costs of teaching a language from an uncritical (or a so-called "neutral") perspective? Our answer to that is that teaching is always a political act and it will, therefore, always have an impact in social reality. The teacher may 
choose, then, to side with the oppressor (by reproducing the status quo without questioning how power and oppression operate in our society). Or s/he may seek another alternative, the one we propose and claim for, that is to equip our students with the necessary tools so as to develop their critical awareness so they will be able to act ethically, responsibly and collaboratively in the world.

\section{REFERENCES}

BASABE, E. A. From De-Anglicization to Internationalization: Cultural Representations of the UK and the USA in Global, Adapted and Local ELT Textbooks in Argentina. Profile 7, p. 59-75, 2006.

BRASIL. Orientações educacionais complementares aos parâmetros curriculares nacionais (PCN+). Linguagens, Códigos e suas tecnologias. Brasília: MEC, 2002. 241p.

BYGATE, M.; SAMUDA, V. Integrative planning through the use of task repetition. In: Planning and task performance in a second language. Amsterdam: John Benjamins, p. 37-74, 2005.

CAUKILL, E. Learning English in an English speaking world: examining opportunities for intercultural understandings and connectedness through representations of identities in English language textbooks. In: DASHWOOD, A.; SON, J.B. (Ed.) Language, Culture and Social Connectedness. Cambridge Scholars Publishing, Newcastle Upon Tyne, 2011. p. $57-73$.

COX, M. I. P.; ASSIS-PETERSON, A. A. Critical Pedagogy in ELT: Images of Brazilian Teachers of English. TESOL Quarterly, v. 33, n. 3, p. 433-452, 1999.

CROOKES, G. V. Critical ELT in action: Foundations, promises, praxis. New York: Routledge, 2013.268p.

D'ELY, R.C.S.F.; MOTA, M. B. The theory, the textbook and the teacher: an analysis of the implementation of oral tasks in foreign language teaching. Linguagem \& Ensino, v. 7, n. 2, p. 65-98, 2004.

ELLIS, R. Task-based language learning and teaching. Oxford: Oxford University Press, 2003.

FERREIRA, A. J.; BRIGOLLA, F. C. A Representação de Gênero em Livros Didáticos de Língua Inglesa. Revista Uniabeu, v. 6, n. 14, p. 1-19, 2013.

FREIRE, P.; MACEDO, D. Reading the word and the world. Massachusetts: Bergin \& Garvey Publishers, INC, 1987.184p.

FREIRE, P. Pedagogia do Oprimido. New York: Herder \& Herder, 1970.183p. 
GRAY, J. The Branding of English and The Culture of the New Capitalism: Representations of the World of Work in English Language Textbooks. Applied Linguistics, v. 31, n. 5, p. 714-733, 2010.

HOBBS, R. Digital and Media Literacy: Connecting Culture and Classroom. California: Thousand Oaks, 2011.214p.

HUMANS OF NEW YORK. Visited on May 19, 2017. Available in: $<$ http://www.humansofnewyork.com>

KELLNER, D.; SHARE, J. Critical media literacy, democracy and the reconstruction of education. In: MACEDO, D.P.; STEINBERG, S.R. (Ed.), Media Literacy: a reader. New York, NY: Peter Lang, 2007, p. 3-23.

LONG, M. Focus On Form: A Design Feature In Language Teaching. In: DE BOT, K; GINSBERG, R.B.; KRAMSCH, C. Foreign Language Research In Cross-Cultural Perspective. Amsterdam: John Benjamin Publishing, 1991.

LONG, M. Second Language Acquisition and Task-Based Language Teaching. Oxford: WileyBlackwell, 2015.

MOITA LOPES, L. P. da Prefácio. In FERREIRA, A. J. (Org.). Identidades sociais de Raça, Etnia, Gênero e Sexualidade: Práticas pedagógicas em sala de aula de línguas e formação de professores/as. Campinas: Pontes Editores, p. 9-12, 2012.

MORAES DA SILVA, J. (2012). Implicações culturais e didáticas do inglês como língua internacional: o livro didático. 2012. (Unpublished Master's thesis) - Departamento de Metodologia do Ensino e Educação Comparada.

PENNYCOOK, A. Introduction: Critical Approaches to TESOL. TESOL Quarterly, v. 33, n. 3, p. 433-452, 1999.

PESSOA, R. R.; URZEEDA-FREITAS, M. T. Challenges in Critical Language Teaching. TESOL Quarterly, v. 46, n. 4, p. 753-776, 2012.

RICHARDS, J.C. Beyond Training. Perspectives on Language Teacher Education. Cambridge: Cambridge University Press, 1998.

ROBERTSON, L.; SCHEIDLER-BENNS, J. Critical Media Literacy as a Transformative Pedagogy. Literacy Information and Computer Education Journal (LICEJ), v.7, n. 1, p. 22472253, 2016.

ROCHA, D. Descompassos da Legislação Brasileira sobre o Trabalho do Professor de Línguas Estrangeiras na Educação Básica. Fórum linguístico, v. 14, n. 1, p. 1667-1681, 2017.

SHOR, I. Empowering Education: Critical Teaching for Social Change. Chicago: Chicago Press, 1992

SKEHAN, P. A framework for the implementation of Task-Based instruction. Applied 
Linguistics. v. 17, p. 62-138, 1996.

TILIO, R. A Representação do Mundo no Livro Didático de Inglês: Uma Abordagem Sócio-Discursiva. The ESPecialist. v. 31, n. 2, p. 167-192, 2010.

TOMLINSON, B. Materials development for language learning and teaching. Language Teaching. v. 45, n.2, p. 143-179, 2012.

VAN DEN BRANDEN, K. Onderwijsvoor de 21ste eeuw. ACCO: Uitgeverij, p. 256, 2015.

VAN DEN BRANDEN, K. Task Based Language Teaching. In: HALL, G. (Ed.), The Routledge Handbook of English Language Teaching, London and New York: Routledge, 2016, p. 238-251.

WILLIS, J.; WILLIS, D. Doing Task Based Teaching: A Practical Guide for Task-Based Teaching for ELT Training Courses and Practicing Teachers. Oxford: Oxford University Press, 2007.

Recebido em: 15/07/2017

Aprovado em: 07/11/2017

Publicado em: 30/12/2017 